\title{
KRITIK SALIM AL-JABI ATAS HERMENEUTIKA MUHAMMAD SYAHRUR
}

\author{
Syamsul Wathani \\ Dosen STAI Darul Kamal NW Aikmel Lombok Timur \\ Email: Wathoni89@gmail.com.
}

\begin{abstract}
Criticism in interpretation studies shows a new phase of the interpretation of the Qur'an in contemporary academic studies of the Qur'an. Muhammad Syahrur is a figure who became the object of criticism for some of his renewed ideas in contemporary studies of the Qur'an which are packaged in hermeneutics. Mahir al-Munanjad passed his book al-iskâ liyat Qirâ ah and Salim al-Jabi, al-Qirâ 'at al-Mu'â shirat. This article focuses on Al-Jabi thinking with analysis on critical points. Al-Jabi made an academic criticism of Syahrur's study, especially in the pattern of the approach used by Syahrur. Al-Jabi offers textual-contextual criticisms of the Shahrur approach patterned on language and thematic-historical analysis, which are often not in the context of the verses of the Qur'an.
\end{abstract}

Keywords: Studies, Qur'an, Hermeneutics, Al-Jabi, Critical view

\begin{abstract}
Abstrak: "Kritik dalam kajian tafsir memperlihatkan fase baru perjalanan tafsir al-Qur'an di kajian akademikkontemporer atas al-Qur'an. Muhammad Syahrur adalah tokoh yang menjadi objek kritikan atas beberapa ide pembaharuannya dalam kajian kontemporer atas alQur'an yang dikemas dalam hermeneutika. Mahir alMunanjad melelui bukunya al-iskâliyat Qirâ'ah dan Salim al-Jabi, al-Qirâ'at al-Mu'âshirat. Artikel ini focus pada pemikiran Al-Jabi dengan analisis pada poin-poin kritik (critical view). Al-Jabi melontarkan kritik akademis atas
\end{abstract}


kajian Syahrur, terutama pada pola pendekatan yang dignakan oleh Syahrur. Al-Jabi menawarkan kritik-kritik tekstual-kintekstual atas pendekatan syahrur yang terpola pada analisis Bahasa dan tematik-historis, yang seringkali tidak sesuai dengan konteks ayat-ayat al-Qur'an.

Kata Kunci : Kajian, Al-Qur'an, hermeneutika, Al-Jabi, Kritik

\section{Pendahuluan}

Tepat sekali sebuah slogan ilmiah yang mengatakan bahwa "alQur'ân ka al-Bahr al-Ladzaî la Sahila lahu", al-Qur'an itu bagaikan laut tanpa tepi. Al-Qur'an tidak pernah habis untuk dikaji, ditafsirkan dan diapresiasi dengan beragam bentuknya dalam kehidupan umat manusia khususnya umat Islam. Kajian terhadap al-Qur'an baik dari segala sisinya tidak pernah mengalami kemandekan. ${ }^{1}$ Inilah barangkali yang menjadikan al-Qur'an selalu menarik untuk didekati dari berbagai aspek dan beragam metodologi. ${ }^{2}$ Ulama' klasik misalnya, lebih sering menafsirkan al-Qur'an dengan pendekatan yang dianggap konvensional di masa itu, yaitu pendekatan sejarah (asbab al-nuzul dan nasihmansukh) dan pendekatan bahasa Arab (linguistik). Dua pendekatan inilah yang mewarnai hermeneutika al-Qur'an di masa Klasik ${ }^{3}$. Sosok seperti Ibn Jarîr Al-Thabarî lebih cenderung menggunakan pendekatan sejarah dalam menafsirkan al-Qur'an karena beliau adalah seorang sejarawan muslim yang terkenal waktu itu.

Hal ini dapat dibuktikan misalnya melalui karyanya yang lain yang dinamakan Târikh al-Thabarî. Sosok seperti Imam Al-Râzî misalnya sangat kental dengan pendekatan bahasanya dalam magnum opusnya tafsir Mafâtih al-Ghaib. Al-Râzî adalah salah seorang mufassir (hemeneut Muslim) yang hebat terbukti dari penjabaran tafsirnya khususnya di bidang kajian bahasa.

1 Waryono Abdul Ghafur, Tafsir Sosial, (Yogyakarta: eLSAQ, 2005), 14.

2 Bandingkan dengan: Ahmad Fuad Fanani, Islam Mazhab Kritis; Menggagas Keberagaman Liberatif, (Jakarta: KOMPAS, 2004), 6.

3 Kamaruddin Hidayat, Memahami Bahasa Agama: Sebuah Kajian Hermeneutika (Jakarta: Paramadina, 1996), 86. 
Perkembangan penafsiran pun hingga kini tidak dapat dibendung. Munculnya tokoh semacam Khalîl Abdul Karîm, Nashr Hamîd Abû Zayd, Muhammad Thalbi, Yaseer 'Audah, Muhammad Syahrûr dan sejenisnya adalah jawaban dari kebutuhan untuk menjadikan alQur'ân Shâlih li kull zamân wa makân ${ }^{4}$. Muhammad Syahrur adalah salah seorang pengkaji al-Qur'an yang sering mendapat perhatian banyak dari para pembaca, peneliti, mufassir dan sebagainya lantaran ia menggunakan pendekatan yang baru dan terkesan nyleneh (baca, gharîb, Arab). Munculnya hermeneutika al-Qur'an yang digagas oleh Muhammad Syahrur khususnya dalam kitab Al-Kitâb Wa al-Qur'ân: Qirâ'at Mu'âshirat lantas memunculkan banyak respon umat muslim pada khususnya dan umat manusia pada umumnya. Sebagian menolak mentah-mentahan baik dengan analisis ilmiah maupun dengan analisis emosi/ sementara di sisi lain ada sejumlah tokoh yang habis-habisan mendukung pemahaman Muhammad Syahrur.

Di antara sekian umat Islam yang menanggapi dan mengkritik hermeneutika Muhammad Syahrur dengan kajian ilmiah serta tidak terjebak pada penilaian negative terhadap sosok Muhammad Syahrur adalah Salim Al-Jabi khususnya melalui bukunya Mujarrâd al-Tanjîm. Salim Al-Jabi tidak seperti Mahir Munajjid yang mengkritik pemikiran Muhammad Syahrur dengan penilaian negatif serta semo'ohan yang berujung pada pengkafiran dan ketidaksucian Islamnya Muhammad Syahrur. Salim Al-Jabi menggunakan pendekatan ilmiah untuk mengcounter pemikiran Muhammad Syahrur yang dituanagkannya dalam bukunya Mujarrâd al-Tanjîm.

\section{Hermeneutika Muhammad Syahrur: Sebuah Pengantar Kritik}

Hermeneutika Syahrur yang cenderung berupaya menemukan makna objektif dengan model subjektif sebenarnya identik dengan metode kebahasaan yang nantinya dikombinasikan dengan teoriteori ilmiah dalam ilmu mekanik yang sering disebut dengan teori hudûd (limit). Adapun metode linguistic Syahrur dipengaruhi oleh dua tokoh yaitu, ${ }^{5}$ pertama, Ibn Jinni dalam Khashaish-nya yang

4 Lihat: Fazlur Rahman, Islam dan Modernitas Transformatif social, terj. Ahsin Muhammad, (Bandung: Pustaka, 1985) 2-3.

5 Abdul Mustaqim, Mempertimbangkan Metodologi Taffsir Muhammad 
mengusung teori (1) Adanya struktur bahasa atau kalimat, termasuk suara sebagai sumber bahasa. (2) Bahasa tidak tercipta dalam satu waktu melainkan berkembang secara evolutif. (3). Bahasa senantiasa mengikuti sistematika atau aturan strukturnya. (4) Perpautan antara bahasa, suara, dengan kondisi psikologis penggunanya. Dan kedua dipengaruhi oleh teori linguistik Imam Jurjâni dalam Dalâ'il alIjaz yang melingkupi struktur bahasa dan fungsi transmisinya serta keterkaitan antara bahasa dengan pemikiran. Bila kedua akumulasi teori ini dikombinasikan, hasilnya adalah: (1). Bahasa mempunyai struktur. (2) Bahasa merupakan penampakan fenomena sosial. (3). Keterkaitan antara bahasa dan pemikiran.

Dari kedua metode yang didapat dari Ibn Jinni dan Imam Jurjani, kemudian Syahrur membuat pembatasan kaedah dasar-dasar metodologi linguistiknya, yaitu: ${ }^{6}$

1. Dalam bahasa tidak ada sinonim, bahkan boleh jadi dalam satu kata memiliki makna yang banyak. Apa yang yang selama ini diyakini sebagai sinonim tidak lebih dari sebuah kepalsuan atau muslihat (khud'ah).

2. Kata adalah ekspresi dari makna

3. Yang terpenting dari bahasa adalah makna.

4. Bahasa apa pun tidak akan dapat dipahami bila tidak ditemukan adanya kesesuaian bahasa itu dengan rasio dan realitas obyektif.

Menurut Syahrur setiap ungkapan dalam bahasa Arab memiliki makna yang independen. Tidak ada kontektualisasi baik bagi teks, penerimaanya maupun penyusunanya. Dengan kata lain al-Qur'an adalah sebuah teks tanpa konteks apapun. Ia adalah teks yang bediri sendiri tanpa ada keterkaitan dengan sejarah ataupun masyarakat yang

Syahrur dalam buku Hermeneutika Alqur'an; Madzhab Yogya (Yogyakarta: Penerbit Islamika, 2003), 123

6 Abdul Mustaqim, Mempertimbangkan Metodologi Taffsir Muhammad Syahrur dalam buku Hermeneutika Alqur 'an; Madzhab Yogya (Yogyakarta: Penerbit Islamika, 2003) 123 
menjadi tujuan pewahyuan itu. Baginya konteks terpenting dalam memahami al-qur'an adalah konteks politik dan intelektual yang menjadi ruang hidup ummat. ${ }^{7}$

Disini Syahrur terkesan bahwa lewat hermeneutika, ia tidak mencari makna tersembunyi di balik teks, melainkan mengarahkan perhatiannya kepada makna objektif dari teks itu sendiri, terlepas dari maksud subjektif pengarang ataupun orang lain. Karena itu, sebuah penafsiran teks bukanlah mengadakan suatu relasi intersubjektif antara subjektifitas pengarang dan subjektifitas pembaca, melainkan hubungan antara dua diskursus teks dan diskursus interpretasi. Interpretasi dianggap sudah berhasil mencapai tujuannya jika dunia teks dan dunia interpreter (penafsir) telah berbaur menjadi satu.

\section{Kegelisahan Salim Al-Jabi}

Salim AL-Jabi sebagai seorang pengkaji yang paham betul dengan kajian lingustik Arab merasa gusar ketika Muammad Syahrur mendekonstruksi beberapa term dan istilah pokok dalam al-Qur'an yang selama ini dianggap telah masyhur (untuk tidak menyebut mapan) baik di wilayah penafsiran al-Qur'an sendiri maupun dalam wilayah kajian linguistic Arab secara umum. Melalui bukunya Al-Kitab Wa alQur'ân: Qirâ'at Mu'âshirat, Muhammad Syahrur mendekonstruksi istilah seperti al-Kitab, al-Qur'ân, al-Furqân, al-Dzikr, nubuwwat dan sebagainya dengan pemahaman baru yang terkesan hanya terjebak dalam arti bahasa belum sampai pada pemahaman makna istilah yang selama ini dikenal dalam arti istilahnya bukan daam arti bahasanya. ${ }^{8}$

Di samping munculnya kegelisahan di atas, Salim al-Jabi diminta oleh rekan-rekannya baik yang secara resmi maupun tidak resmi untuk mengcounter pemikiran Muhammad Syahrur yang berbeda dari para pengkritik lainnya. Hal ini disadari karena banyaknya para pengkritik yang tidak objektif dan cenderung terjebak pada pengkafiran dan kritik

7 Dikutip dari tulisan Burhanuddin, Artikulasi Teori Batas (Nazariyyah al Hudud) Muhammad Syahrur dalam Pengembangan Epistimologi Hukum Islam di Indonesia dalam buku Sahiron Syamsuddin, dkk. Hermeneutika Alqur'an; Madzhab Yogya, (Yogyakarta: Penerbit Islamika, 2003), 152

8 Salim al-Jabi, al-Qira'at al-Mu'ashirat li al-Duktur Muhammad SYahrur: Mujarrad al-Tanjim, (Damaskus: AKAD, 1991) 6. 
eksternal yang tidak ilmiah dan penuh muatan ideologis. ${ }^{9}$ Berangkat dari dua kegelisahan inilah Salim al-Jabi mencoba mengcounter pemikiran Muhammad Syahrur dengan pendekatan bahasa sebagaimana yang digunakan oleh Muhammad Syahrur untuk kajian terhadap istilahistilah pokok dalam al-Qur'an.

\section{Pendekatan Bahasa Vis a Vis Historis-Tematis Kontekstual}

Rumusan hermeneutika Salim al-Jabi dilatarbelakangi oleh hermeneutika Muhammad Syahrur. Lebih tepatnya counter terhadap buku al-Kitâb wa al-Qur'ân: Qirâ'aat Mu'âshirat, sehingga berangkatnya adalah dari term-term yang telah diungkapkan oleh Muhammad Syahrur ${ }^{10}$ di dalam buknya al-Kitâb wa al-Qur'ân: Qirâ'aat Mu'âshirat. Di antara beberapa pokok dari rumusan kritik Salim al-Jabi terhadap hermeneutika Muhammad Syahrur adalah yang

9 Salim al-Jabi, al-Qira'at al-Mu'ashirat li al-Duktur Muhammad SYahrur: Mujarrad al-Tanjim, (Damaskus: AKAD, 1991) 6.

10 Sebuah teori mengatakan bahwa setiap kegiatan intelektual yang memancar dari suatu kegelisahan tidak dapat dipisahkan dari problematika sosial yang melingkupinya. Muhammad Syahrūr, dalam menelorkan ide-idenya, khususnya terkait dengan masalah keislaman, tidak lepas dari teori ini. Ide-idenya muncul setelah secara sadar mengamati perkembangan dalam tradisi ilmu-ilmu keislaman kontemporer. Didasarkan atas teori bahwa kebenaran ilmiah sifatnya tentatif, Syahrūr lalu mencoba mengelaborasi kelemahan-kelemahan dunia Islam dewasa ini. Di antaranya adalah tidak adanya metode penelitian ilmiah yang obyektif, khususnya terkait dengan kajian Nash (ayat-ayat al-Kitab) yang diwahyukan kepada Muhammad. Di samping itu, menurut Syahrur kajian-kajian keislaman yang ada seringkali bertolak dari perspektif-perspektif lama yang dianggap sudah mapan, yang terperangkap dalam kungkungan subyektifitas, bukan obyektifitas. Kajian-kajian itu tidak menghasilkan sesuatu yang baru, melainkan hanya semakin memperkuat asumsi yang dianutnya. Lebih dari itu Syahrur melihat tidak dimanfaatkannya filsafat humaniora, lantaran umat Islam selama ini masih mencurigai pemikiran Yunani (Barat) sebagai keliru dan sesat. Karena itulah Syahrūr sangat bersikeras bahwa tiaptiap generasi mampu memberikan interpretasi al-Qur`an yang memancar dari realitas yang muncul dan sesuai dengan kondisi di mana mereka hidup. Hasil interpretasi alQur`an generasi awal tidaklah mengikat masyarakat Muslim modern. Bahkan lebih jauh, kesalahan utama fiqh Islam dan tafsir al-Qur`an konvensional sekarang ini bersumber dari kesalahan metodologi yang tidak memperhatikan karakteristik dan fleksibilitas pengertian teks-teks Kitab Suci, sehingga membebani punggung umat dan tidak sesuai lagi dengan kemajuan ilmu pengetahuan serta situasi dan kondisi abad ke-20. Syahrūr yakin bahwa Muslim modern, karena kemajuan budaya dan ilmu pengetahuan mempunyai perangkat pemahaman metodologis yang lebih baik dibandingkan para pendahulunya (abad ke-7 M) dalam memahami pesan-pesan Allah (al-Qur’an) yang disampaikan kepada Rasul-Nya. 
terkait dengan boleh tidaknya "qiraah muasirah" untuk kajian alQur'an. Muhammad Syahrur memang secara tegas mendeklarasikan dirinya sebagai seorang yang mengusung pola pembacaan "qirâ'ah mu'âsirah" dalam mengkaji al-Qur'an. Hal ini sebagaimana digambarkan dengan tegas dalam judul bukunya al-Kitâb wa al-Qur'ân: Qirâ'aat Mu'âshirat. Muhammad Syahrur kemudian menggunakan pendekatan sains khususnya mekanika tanah dalam mendekonstruksi term-term yang selam ini dianggap mapan dalam studi Islam.

Secara konseptual, Menurut Al-Jabi apa yang digagas oleh Muhammad Syahrur dengan "qiraah muasirah"nya adalah hal yang sah-sah saja karena ia mencoba untuk meberikan penafsiran baru terhadap beberapa aspek dalam al-Qur'an. Hal semacam ini di sisi lain juga merupakan fitrah pemikiran di mana dalam setisap dekade dan masa selalu ada pemikiran baru yang ditawarkan. Bahkan dengan tegas al-Jabi mengatakan bahwa setiap zaman memiliki konteks hermenutikanya sendiri-sendiri. Melihat kenyataan inilah Salim alJabi kemudian mengkritik Syahrur bahwa proyek yang sedang ia garap belumlah sampai kepada proyek yang sempurna. Karena menurut alJabi, Sayhrur justru terjebak dalam pola-pola pemaknaan istilah yang sempit karena dilatarbelakangi oleh pemahaman Syahrur terhadap makna kata secara bahasa (bukan secara istilah) yang kemudian di bawa ke makna yang mapan (istilah). ${ }^{11}$

Kritikanal-Jabiberlanjut bahwa dekonstruksiyang dilakukan oleh Syahrur lebih karena dilatarbelakangi oleh ketidak-ahlian Muhammad Syahrur dalam bidang linguistik Arab. Sehingga dampaknya adalah kegegabahan Syahrur dalam menarik makna bahasa menjadi makna istilah yang diharapkan menjadi makna yang mapan. Bahasa Arab memiliki ciri khas dan makna yang memiliki kesejarahannya sendiri. Bahasa Arab sangat kaya dengan lahjah dan penggunaan makna yang beragam. Belum lagi jika dikaitkan dengan al-Qur'an ketika turun. Makna apa yang dikehendaki oleh al-Qur'an ketika ia turun juga mustinya mendapa perhatian yang serius dari Syahrur. Jika landasan linguistic ini tidak diindahkan maka Syahrur bias jatuh dalam dekonstruksi bebas tanpa landasan yang bisa berujung pada perubahan

11 Salim al-Jabi, al-Qirâ'at al-Mu'âshirat li al-Duktur Muhammad SYahrur: Mujarrad al-Tanjîm, (Damaskus: AKAD, 1991), 14-17. 
pedoman umum pemahaman qur'an seperti dukun yang mengadangada tanpa sumber yang valid. ${ }^{12}$

Hal mendasar yang menurut Al-Jabi sangat ironis adalah bahwa Syahrur tidak begitu memahami term-term yang ia rubah maknanya dan lebih dari itu yang sangat ironis adalah bahwa Syahrur tidak memperhatikan kaidah-kaidah pokok dan landasan ilmiah awal ketika berijak di dunia linguistic Arab malahan ia terjerumus dalam otak-atik seperti layar optik yang diotak-atik dan seperti layaknya perdukunan yang mengada-ngada tanpa fakta sedikitpun. ${ }^{13}$

Al-Jabi tidak secara tegas menjelaskan alur pemahamannya terhadap al-Qur'an. Namun dari pengantar bukunya setidaknya dapat dirumuskan model pemahaman (hermeneutika) dari al-Jabi di dalam bergumul dan bertegur sapa dengan al-Qur'an, yaitu dua pendekatan pokok, yakni pendekatan bahasa dan pendekatan historis-tematiskontekstual, meskipun pendekatan bahasa sangat lebih dominan dibandingkan dengan pendekatan yang kedua. Namun kedua hal inilah yang selalu tidak bisa dipisahkan dari al-Jabi ketika menafsirkan beberapa term atau ayat al-Qur'an. Untuk selanjutntya penulis akan menjelaskan beberapa poin dari rumusan hermeneutika al-Jabi yang muatannya adalah counter terhadap pemikiran Syahrur sehingga tak ayal jika tema yang ada adalah tema-tema yang dibahas oleh Syahrur seperti ayat muhkamat-ayat mutasyâbihât, kerancuan qirâ'at mu'âshirat, nubuwwah, al-dzikr dan al-furqân.

\section{Rumusan Hermeneutika Salim Al-Jabi;}

Model hermeneutika Al-Jabi cenderung sebagai counter ilmiah terhadap hermeneutika Syahrur. Untuk itu secara konseptual terkait dengan beberapa term yang sudah dijelaskan oleh Syahrur dalam kitabnya "al-Kitab Wa al-Qur'ân : Qirâ'at Mu'âshirat". Di antaranya adalah beberapa istilah sebagai berikut:

12 Salim al-Jabi, al-Qirâ'at al-Mu'âshirat li al-Duktur Muhammad SYahrur: Mujarrad al-Tanjîm, (Damaskus: AKAD, 1991), 14-17.

13 Salim al-Jabi, al-Qirâ'at al-Mu'âshirat li al-Duktur Muhammad Syahrur: Mujarrâd al-Tanjîm, (Damaskus: AKAD, 1991), 14-17 


\section{Ayat Muhkamat dan Ayat Mutsyabihat}

Menurut Syahrūr, al-Qur'an dalam arti yang populer, atau dalam bahasa Syahrūr "al-Kitab", terbagi dalam tiga macam : 1) ummu alkitâb (ayat-ayat muhkamat); 2) al-Qur'ân wa sab'u al-matsâni (ayatayat mutasyabihat); dan 3) tafsilu al-kitab. ${ }^{14}$ Ummu al-kitab, yang diturunkan langsung dari Allah kepada Nabi selama 23 tahun dalam bentuk al-inzâl dan al-tanzîl secara tak terpisahkan, memuat ayatayat yang berkaitan dengan al-sulukk al-insâni dalam bidang hukum dan akhlaq dan terbuka untuk dilakukan ijtihad (bukan dalam ibadah murni) sesuai dengan situasi dan kondisi masyarakat tertentu. Hasil interaksi intelektual masyarakat dengan ummu al-kitab pada satu masa bisa jadi berbeda dengan hasil interaksi mereka yang hidup pada masa yang lain. Karena itu, menurut dia, praktek penerapan hukum pada masa Nabi (baca : al-sunnah) adalah hanya model awal penafsiran, dan bukanlah satu-satunya bentuk aplikasi hukum ummu al-kitab yang sesuai sepanjang jaman.

Menanggapi pemahaman Syahrur di atas, al-jabi melihat bahwa dalam memahami istilah ayat muhkamât dan ayat mutsyâbihat diperlukan setidaknya tiga analisis, yaitu: 1) analisis kebahasaan, 2) analisis tematik kontekstual al-Qur'an. Dalam hal analisis kebahasaan, al-Jabi mengartikan bahwa secara bahasa kata muhkam adalah sesuatu yang telah tetap dan tidak menerima sedikitpun perubahan. Sedangkan mutasyabih menurut bahasa adalah serupanya dua hal dalam bidang tertentu sehingga harus ditentukan mana musyabbahnya, musyabbah bihnya dan waj al-syabahnya. ${ }^{15}$ Sehingga dalam hal ini menurut al-Jabi semua al-Qur'an secara keseluruhan pada dasarnya adalah muhkam dalam arti tidak ada perubahan sedikitpun di dalamnya sehingga Allah berfirman:

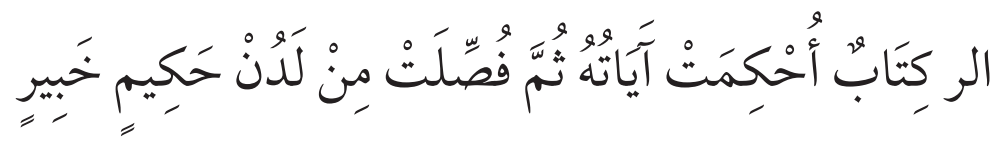

14 Muhammad Syahur, Prinsip dan Dasar Hermeneutika al-Qur'an Kontemporer, terj. Sahiron Syamsuddin,.(Yogyakarta: eLSAQ Press, 2004, 51-61)

15 Salim al-Jabi, al-Qirâ'at al-Mu'âshirat li al-Duktur Muhammad Syahrur: Mujarrad al-Tanjim, (Damaskus: AKAD, 1991), 29. 
Dengan demikian baik ayat muhkamat atau mutasyabihat secara keseluruhan pada dasarnya adalah ayat muhkamat dalam arti tidak ada sediktpun ayat yang dirubah. Adapun letak perbedaan di antara keduanya terletak pada model kandungannya. Ayat muhkamat itu ajaran-ajaran yang murni dan berasal dari Nabi Muhammad sedangkan ayat mutasyabihat adalah ajaran-ajaran yang diambil (untuk tidak mengatakan diadopsi) dari perjanjian lama dan perjanjian baru (taurat dan injil).

Kemudian dalam menganalisis ayat yang terkait dengan muhkamat dan mutsyabihat al-Jabi layaknya Syahrur menganalisis ayat 7 dari Q.S. Ali Imran. Bagi al-Jabi, agar tercapai pemahaman yang menyeluruh terkait dengan muhkamat dan mutsyabihat yang terdapat di ayat 7, al-Jabi menjelaskan secara keseluruhan kandungan surat Ali imran sehingga bisa diketahui kandungan teks-teks tersebut dengan sempurna.

Ayat yang pertama dan kedua menjelaskan tentang misi penetapan sifat Allah. Ayat ketiga dan keempat menjelaskan kronologi penyampaian misi tersebut dengan melalui kitab-kitab terdahulu. Ayat ke lima dan ke enam merupakan bukti ilmiah yang nyata dari misi di atas. Sedang ayat ke tujuh menjelaskan tentang kandungan ajaran al-Qur'an yang tidak semuanya baru, namun sebagain merupakan ajaran baru dan sebagian lain menyerupai ajaran-ajaran kitab samawi sebelumnya. Dalam ayat ke tujuh juga dijelaskan bahwa manusia beragam modelnya dalam menanggapi keadaan tersebut. Dan seterusnya menurut al-Jabi merupakan manifestasi dari kerangka beberapa kandungan ajaran al-Qur'an yang sebagain adalah baru dan sebagain lain merupakan ajaran yang menyerupai ajaran yang terdapat dalam taurat dan injil.

\section{Nubuwwat}

Syahrur memandang sosok penerima wahyu yaitu Muhammad dapat sebagai seorang Rasul dan seorang Nabi. Oleh karena itu, al-Kitâb yang diwahyukan kepdanya harus mencakup unsur-unsur kerasulan (risalah) dan kenabian (nubuwwah)nya. Maka, dapat disimpulkan bahwa al-Kitab terdiri dari dua tema utama, yaitu: 
1) Kitab al-Risalah, terdiri dari kaidah moralitas (kode etik) bagi manusia, baik berupa ibadah, muamalah, dan akhlak. Secara konkrit, kitab risalah berupa ayat-ayat muhkamat yang diidentifikasi dengan sebutan umm al-kitab (induk kitab).

2) Kitab al-Nubuwwah, terdiri dari himpunan tema-tema yang mencakup pengetahuan alam dan sejarah, dan bukti hakikat eksistensi objektif yang diwujudkan berupa ayat-ayat mutasyabihat, yaitu al-Qur'an.

Menanggapi pembedaan istilah yang digunakan oleh syahrur, Al-Jabi menganalisis dengan pendekatan kebahasaan dan pendekatan tematik kontekstual al-Qur'an. Pertama, pendekatan kebahasaan. Dalam al-Qur'an dijumpai istilah Nabiyy yang dalam bahasa Arab merupakan sifat musyabbihat bi ism al-Fa'il yang diambil dari masdar yaitu kata nubuwwat. Kata nabiyy sendiri diambil dari tiga kata yang beragam, yaitu 1) dari kata nubuww yang artinya tinggi maksudnya seorang yang memiliki tingkat keruhaniyan yang mulia, luhur dan tinggi. 2) dari kata Nabi' un yang artinya jalan yang terang, maksudnya adalah jalan hidup yang jelas dari seseorang yang telah mencapai tingkatan kenabian dan 3) dari kata Naba' yang artinya berita yang benar-benar besar, maksudnya adalah seseorang yang dating dengan berita yang benar dan berita yang sangat besar. Kemudian al-Jabi menambahkan arti yang keempat (4) dengan sebuah sebutan yang diberikan Allah kepada seseorang yang berkarakter seperti karakter Tuhannnya yang Maha Suci. Dengan demikian setidaknya seorang Nabi menurut Al-Jabi harus memiliki keempat sifat di atas.

Kedua, pendekatan pendekatan tematik kontekstual al-Qur'an. Menurut al-Jabi, al-Qur'an sama dengan pendapat para ahli bahasa bahwa setiap seorang Nabi itu sebelum diangkat menjadi Nabi sudah memiliki empat karakter yang disebutkan di atas. Hal ini dapat dilihat misalnya:

a) Q.S. al-Anfal ayat 64:

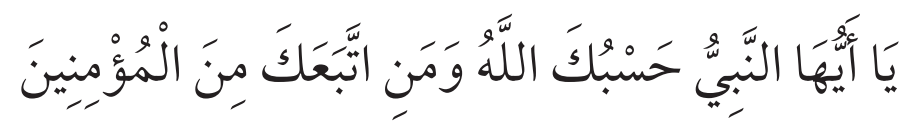


b) Q.S. al-Taubah

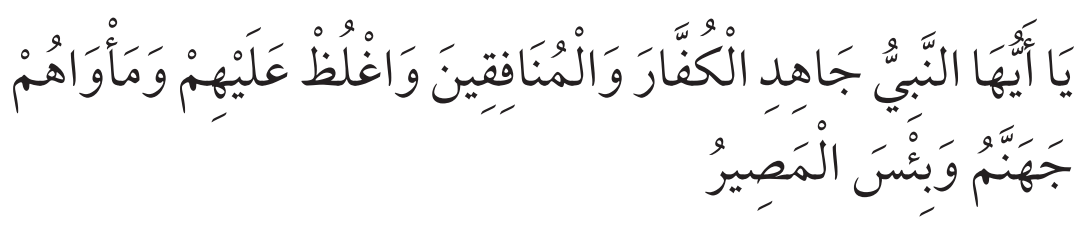

c) Q.S. Al-Ahzab ayat 1:

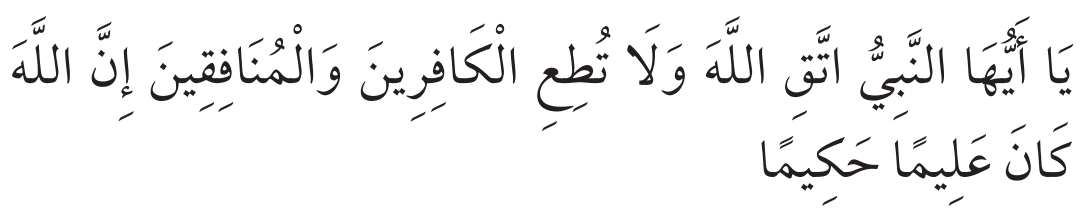

d) Dan Lain-lain

Sehingga dengan demikian nubuwwat adalah sebuah tingkatan derajat yang diagapai oleh seseorang yang memenuhi 4 syarat di atas. Baik dia menerima tanggungjawab syari'at maupun tidak. Namun ada yang mebedakan bahwa seorang Nabi tidak mendapatkan tugas tasyri' (menyampaikan syari'at) sedangkat rasul mendapatkan tasyri' (menyampaikan syari'at). Dan di samping itu ada juga yang menyakaman di antara keduanya sehingga seorang nabi adalah seorang Rasul dan sebaliknya seorang Rasul adalah seorang Nabi.

\section{Al-Dzikr}

Kemudian terkait dengan terma "al-Dzikr", Syahrur menjelaskan bahwa al-Dikrz merupakan sebuah proses transformasi al-Qur'an dari tahapan pra-linguistik menjadi berbentuk linguistik yang dapat dipahami oleh sistem bahasa manusia, yang secara konkrit berujud bahasa Arab. Bagi Syahrur al-Qur' an hanyalah merupakan bagian dari mushaf, yang merupakan kumpulan sistem peraturan obyektif bagi eksistensi dan realitas perilaku dan peristiwa-peristiwa kemanusiaan. Adapun al-Dzikr adalah proses terjadinya al-Qur'an (dari Lauh Mahfudz) ke bentuk bahasa manusia yang diucapkan dalam bahasa Arab. Definisi-defenisi seperti ini diperoleh setelah Syahrūr melakukan kajian semantik dengan analisa paradigma-sintagmatisnya. ${ }^{16}$

16 Muhammad Syahur, Prinsip dan Dasar Hermeneutika al-Qur'an 
Dengan asumsi pembedaan antara term al-Kitab, al-Qur'an, alDzikr, dan al-Furqân, Syahrūr membangun diskursus tafsir dan fiqh kontemporernya. Fakta adanya perdebatan ulama linguistik tentang eksistensi taraduf, nampaknya tidak membuatnya bergeming. Ia tetap bersikukuh dengan penolakannya terhadap taraduf dan terus mengembangkan teorinya dalam melakukan pembacaan kontemporer terhadap al-Qur'an. Hal ini dapat dilihat dalam buku-buku yang dikarangnya belakangan, "Jika kita memandang sebuah buku tentang kedokteran atau tehnik yang ditulis dalam bahasa apapun, maka kita tidak akan menemukan fenomena sinominitas di dalamnya.

Definisi yang digagas oleh Syahrur menurut Al-Jabi tidak logis karena tidak memiliki landasan analisis kebahasaan yang memadai dan tidak begitu memperhatikan kandungan umum al-Qur'an. Meski Al-Jabi sempat menyebut kata-kata yang secara tidak langsung untuk menyudutkan Syahrur, namun Al-Jabi pun tidak terjebak dengan penilaian negative terhadap sosok Syahrur melainkan ia konsisten dengan menggunakan pendekatan sejarah dan kajian tematik kontekstual terhadap teks Al-Qur'an. ${ }^{17}$

Al-Jabi menjelaskan bahwa secara bahasa adalah isim sifat yang digunakan untuk menyebut beberapa nama dari al-Qur'an. Hal ini didasarkan pada fakta bahwa Allah SWT memberikan beberapa nama tertentu untuk menyebut al-Qur'an. Di sini Al-Jabi mengkritik Syahrur yang menggunakan satu sumber (kamus) dalam mengartikan al-Dzikr dan mengabaikan sumber lainnya, mustinya Syahrur menyebutkan semua makna dari kata yang dimaksud agar ia tidak jatuh pada kecerobohan dalam mengkaji suatu makna. Terlebih jika Syahrur bertekad untuk menjadikan kajiannya sebagai kajian kontemporer "Qirâ'at Mu'âshirat", tentu hal ini sangatlah ironis karena ia berharap kajiannya komprehensif tapi langkah-langkah akademis terkait analisis kebahasaan tidak ia lakukan.

Sebagaimana dijelaskan di atas, Syahrur mendefinisikan bahwa al-Dikrz merupakan sebuah proses transformasi al-Qur'an dari tahapan

Kontemporer, terj. Sahiron Syamsuddin,.(Yogyakarta: eLSAQ Press, 2004, 51-71)

17 Salim al-Jabi, al-Qirâ'at al-Mu'âshirat li al-Duktur Muhammad Syahrur: Mujarrad al-Tanjim, (Damaskus: AKAD, 1991), 139. 
pra-linguistik menjadi berbentuk linguistik yang dapat dipahami oleh sistem bahasa manusia, yang secara konkrit berwujud bahasa Arab. Meski di satu sisi Ia menjelaskan bahwa kata kerja "Dzakara" bisa bermakna mengingat atau lawan kata dari lupa seperti firman allah "Afalâ tadzakkarûn". Namun demikian ia tidak menganalisis maknamakna dari al-dikzr secara bahasa dan secara sepontan mendefinisikan nbahwa al-Dzikr merupakan proses transformasi al-Qur'an dari tahapan pra-linguistik menjadi berbentuk linguistik yang dapat dipahami oleh sistem bahasa manusia, yang secara konkrit berwujud bahasa Arab. ${ }^{18}$

Jika dikaji secara mendalam menurut bahasa kata al-Dzikr setidaknya memiliki beberapa makna, yaitu, menjaga sesuatu, suara, pujian, kemuliaan, do'a, memohon kepada dan mengingat Allah, member nasehat dan mengingatkan. Dan jika dikaji semua ayat yang di dalamnya terdapat kata dzikr maka tidak dijumpai satupun ayat yang menunjukkan arti suara bahasa Arab sebagaimana makna yang digunakan oleh Muhammad Syahrur. Dengan demikian secara bahasa kajian Syahrur patut diragukan khususnya oleh kalangan pengkaji bahasa Arab dan orang-orang penduduk asli Arab khususnya.

\section{Konsep al-Umm dalam al-Qur'an: Metode pemahaman al-Qur'an Al-Jabi}

\section{Asal kata al-Umm}

Sebagian ulama' menganggap asal kata (الأم) adalah (المهة) (الام)( Pendapat ini didasarkan pada jama' lafal (الأمهات) : (الأم). Hanya saja, karena alasan takhfif dan talbis, maka huruf ha nya dihilangkan. ${ }^{19}$ Pendapat lain mendasarkan lafal ini dengan (ألأمات) atau (أميمة). Yang lain mengumpulkan pendapat ini dengan mengatakan bahwa makna keduanya sama. Hanya saja, yang pertama seringkali dipakai untuk menunjuk kepada manusia, sedang yang ke-dua diperuntukkan untuk golongan binatang ${ }^{20}$.

18 Salim al-Jabi, al-Qirâ'at al-Mu'âshirat li al-Duktur Muhammad SYahrur: Mujarrâd al-Tanjîm, (Damaskus: AKAD, 1991), 140.

19 Lihat: Muhammad ibn mandhur, Lisân al- 'arob. CD ROM. al-Maktabah al-Shamilah. Kûtub el-Barnamij fî al-lughoh wa al-ma'âjim, Vol 12, 22

20 Diantara yang berpendapat demikian adalah al-Azhary, Lihat : Muhammad al-husainy,Taj al'arus min jawahir al-qomus. CD ROM. al-Maktabah al-Shamilah. Kutub el-Barnamij fi al-lughoh wa al-ma'ajim, Vol 36, 327 
Adapun kemungkinan asal dari fi'il-nya. adalah amma yaummu yang berarti memimpin, atau melukai kulit. (ashāba umma dimāghihi $)^{21}$. Atau berkeinginan kuat terhadap sesuatu dan berusaha menuju yang diinginkan (dengan mashdar : immatun). FirmanNya : "Dan jangan (pula) mengganggu orang-orang yang (bermaksud)

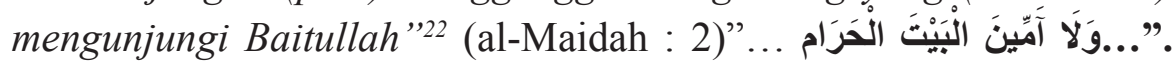
Juga Tayammum secara bahasa adalah bentuk perubahan dari taammum yang berarti berkehendak. ${ }^{23}$

\section{Makna al-Umm dalam tradisi kebahasaan Arab}

Lawan kata dari al-Abu, yang berarti ibu yang melahirkan. Sama saja, apakah ia ibu dekat (yang melahirkan kita), ataukah ibu jauh (yang melahirkan orang yang melahirkan kita). Itulah mengapa Hawā' juga disebut (أمنا). Juga dapat berarti sesuatu yang menjadi landasan bagi keberadaan, perkembangan, ataupun perbaikan sesuatu yang lain. alKholīl menyebutkan : setiap hal yang meliputi segala hal disekitarnya dinamakan al-Umm. Sebagaimana firmanNya yang menamai al-Laūh al-Mahfüdz dengan al-Umm, karena (diyakini) bahwa segala ilmu

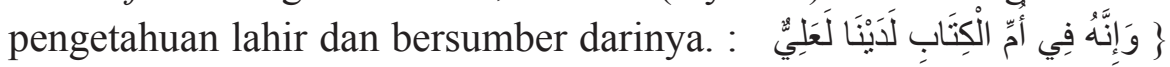

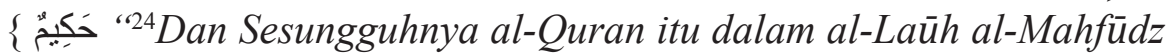
di sisi kami, adalah benar-benar Tinggi (nilainya) dan amat banyak mengandung hikmah. (al-Zukhrūf : 4)"25 Inilah mengapa, Makkah juga disebut dengan umm al-Qurā. Karena ada sebuah riwayat, bahwa dunia ini, menyebar darinya.

Allah berfirman: "Demikianlah kami wahyukan kepadamu Al Quran dalam bahasa Arab, supaya kamu memberi peringatan kepada

21 Lihat : al-Raghîb al-Ashfahâny>, al-Mufrodât $f>i$ ghorîb al-qur'ân, (Kairo : al-Maktabah al-Taufiqiyyah) tt. 32.

22 Muhammad bin Jarir bin Yazid bin Katsir bin Ghalib al-Amili, Abu Ja'far Al-Thabari. 'Tafsir al-Thabari'. CD ROM. al-Maktabah al-Shamilah. Kutub el-Barnamij fi al-Tafsir, Vol 9, 471

23 Lihat : Muhammad al-husainy,Taj al'arus...Vol 31, hlm. 228, bandingkan dengan : Muhammad ibn mandhur, ,Lisan al- 'arob. ...Vol 12, 22

24 Dalam proses transliterasi, penulis banyak terbantu dengan soft ware qur'anic in word. Hanya saja, ini tidak berarti bahwa hasil terjemahan yang dicantumkan adalah saduran an sich. Karena setiap transliterasi tersebut, terlebih dahulu dibandingkan dengan beberapa kitab tafsir klasik maupun keterangan dari kitab lughoh dari mana keterangan tentang ayat tersebut dikutip.

25 al-Thabari. 'Tafsir al-Thabari'.... Vol 21, 566 
umm al-Qurā (penduduk Makkah), dan penduduk (negeri-negeri)

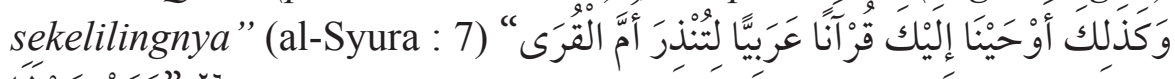

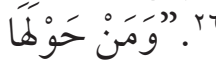

Orang arab juga terbiasa menyebut panglima perang dengan sebutan umm al-Jaisy, sebagaimana sebuah syair yang bermakna : "aku telah melihat seorang panglima atas jiwa - jiwa prajurit yang mulia itu. وأم عيال قد شهدت نفوسهم Surat al-Fatihah juga dinamakan Umm $a l-k i t a \bar{b}$, karena ia adalah awal al-Qur'an. al-Umm juga berarti tempat kembali sebagaiman firmanNya : "maka tempat kembalinya adalah

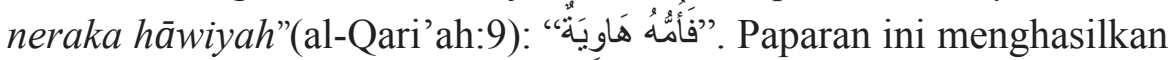
konklusi sederhana, bahwa makna - makna dalam setiap kutipan tersebut, berada dalam satu muara makna, sesuai dengan apa yang diistilahkan oleh al-Kholil

\section{Derivasi kata $a l-U m m$ : makna isytiqāqī-nya}

Dengan memperhatikan model - model makna yang dapat diuraikan dari asal kata umm, disimpulkan bahwa hubungan makna secara semantis (isytiqāqü)-nya adalah "adanya ikatan yang kuat". Dalam contoh dasarnya, al-Umm berarti ibu yang mengikat anak - anaknya dalam tautan kasih sayang dan cinta. Selain dalam kapasitasnya sebagai induk, juga bahwa dialah yang ikut mengatur kehidupan rumah tangga.

a. Ummah $\rightarrow$ Umam. Yaitu sekumpulan orang yang diikat oleh satu kesamaan. Entah itu agama, zaman, tempat ataupun yang lainnya, tak terbatas apakah kesamaan tersebut bersifat pasti ataukah pilihan. FirmanNya : "Dan tiadalah binatang-binatang yang ada di bumi dan burung-burung yang terbang dengan kedua sayapnya, melainkan umat (juga) seperti kamu"(al-An'am : 38).

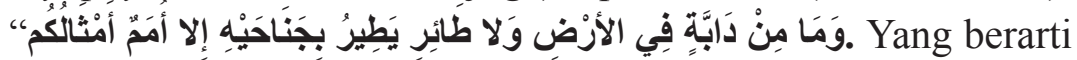
: Setiap kelompok tersebut hidup sesuai tabiat yang digariskan olehNya. FirmanNya yang lain: "Manusia itu adalah umat yang satu. (Setelah timbul perselisihan), Maka Allah mengutus para nabi, sebagai pemberi peringatan,... “(al-Baqarah: 213), yang

26 Muhammad al-Raghib al-Ashfahany, al-Mufrodat fi ghorib....., 33 
berarti manusia itu pada awalnya adalah dalam satu kelompok yang kufur dan sesat”.........

b. Hubungan semantisnya adalah : umat adalah kesatuan kelompok yang diikat oleh persamaan idealism, agama, ras, jenis, tempat dan sebaginya.

c. Ummah yang bermakna agama. Dalilnya, adalah pernyataan orang arab : fulān lā ummata lah, yang berarti fulān lā dīna lah.

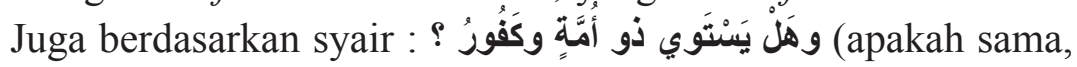
orang yang beragama dengan orang yang inkar?. Firman Allah

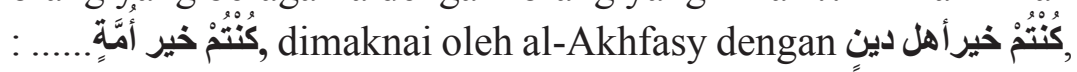
"Kalianlah sebaik - baiknya orang yang beragama..."28

d. Hubungan isytiqāqū-nya : agama merupakan sesuatu variable penting yang menyatukan pengikut - pengikutnya dengan struktur ideologis tertentu.

e. al-Ummy: Seseorang yang tak bisa menulis dan (tidak bias pula) membaca. Sebagaimana yang ditunjukkan oleh ucapan Allah dalam al-Qur'an : "Dia-lah yang mengutus kepada kaum yang buta huruf seorang Rasul di antara mereka, yang membacakan

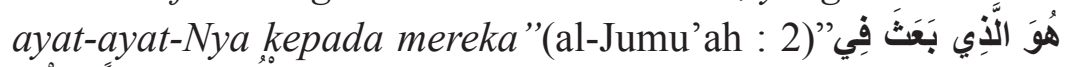

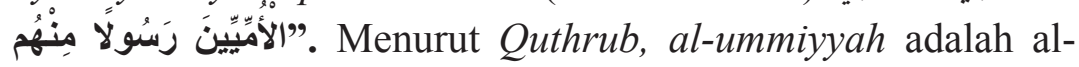
ghoflah wa al-jahalah (kelalaian dan kebodohan). FirmanNya : "Dan diantara mereka ada yang buta huruf, tidak mengetahui Al Kitab (Taurat), kecuali dongengan bohong belaka dan mereka Hanya menduga-duga..."(al-Baqarah : 78). Yang artinya, meraka tidak mengetahui apa - apa kecuali apa yang dibacakan atas

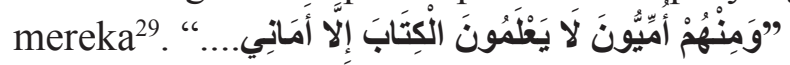

al-Farra' menyebutkan makna yang lebih khusus. al-Ummiyyun berarti bangsa arab yang belum pernah mendapatkan kitab (samawi) sebelumnya. Allah berfirman: “ (Yaitu) orang-orang yang mengikut rasul, nabi yang ummi yang (namanya) mereka

27 Muhammad al-Raghib al-Ashfahany, al-Mufrodat fi ghorib.......33

28 Lihat: Muhammad ibn mandhur, ,Lisan al- 'arob.....Vol 12, . 22

29 Muhammad al-Raghib al-Ashfahany, al-Mufrodat fi ghorib........1 33

\begin{tabular}{l|l} 
Kritik Salim al-Jabi Atas Hermeneutika... & 161
\end{tabular} 
dapati tertulis di dalam Taurat dan Injil yang ada di sisi

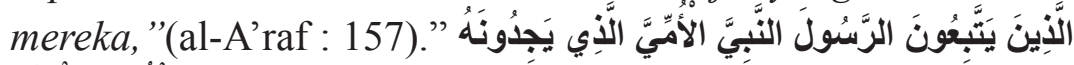

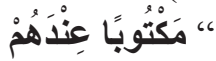

f. Sifat ummi dalam ayat lain dirujukkan kepada segolongan manusia yang tidak memiliki kebiasaan menulis maupun membaca buku - buku tetapi kental dengan tradisi hafal -menghafalnya. Sebagaimana tersirat dalam firmanNya : "Kami akan membacakan (Al Quran) kepadamu (Muhammad) Maka

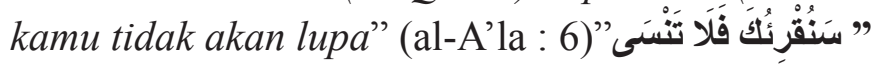

Hubungan semantisnya : bahwa orang yang buta huruf (tak bisa baca-tulis) terikat daya kreativitasnya. Sehingga ia tidak bisa bebas bergerak dan berekspresi. Seakan kekurangan itu mengekangnya.

g. al-Imam $\rightarrow$ al-Aimmatun : seseorang yang diikuti, yang memimpin dengan perkataan, perkataan serta wewenangnya. FirmanNya :"(Ingatlah) suatu hari (yang di hari itu) kami

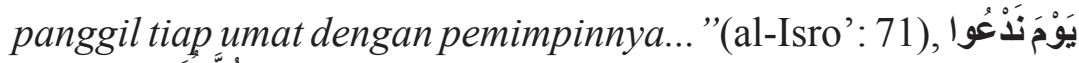
كُلَّ أنَاسِ بِِِمَامِهِنْ al-Imām dalam ayat ini dengan dengan al-kitāb atau al-nabi. ${ }^{30}$

Ia juga dapat berarti al-Laūh al-Mahfūdz, Firman Allah: "Dan segala sesuatu kami kumpulkan dalam Kitab Induk yang nyata (Lauh mahfuzh).”(Yaasiin : 12)" وَكُلَّ شَيْيَ "أحْرَيْنَاهُ فِي إِمَامِ مُبِينٍ

Hubungan semantisnya : imam adalah seseorang yang memiliki kekuasaan dan pengaruh sehingga ia bisa mengatur anggota kelompoknya dengan peraturan - peraturan dan ikatan - ikatan.

\section{Posisi al-Jabi di Antara Madzhab-madzhab Hermeneutika}

Sejarah mencatat bahwa pada awalnya, hermeneutika hanya digunakan oleh para philosof Kristen dalam memahami atau

30 Bandingkan dengan Muhammad ibn mandhur, ,Lisan al- 'arob... Vol 12, 
menafsirkan Bibel yang sudah terkontaminasi oleh kondisi para pengarangnya ketika kitab tersebut ditulis. Fredrich Scleirmacher -seorang teolog Protestan- merupakan orang yang pertama kali memperluas wilayah hermeneutika dari sebatas teknik interpretasi kitab suci (Biblisce Hermeneutik) menjadi 'hermeneutik umum'. Kemudian muncul Dilthey yang menekankan gagasan 'historitas teks' dan pentingnya 'kesadaran sejarah'. Seorang pembaca teks menurut pemikir asal jerman ini, harus berpikir kritis terhadap teks beserta konteks sejarahnya, meskipun di saat yang sama dituntut untuk berusaha melompati 'jarak sejarah' anatara masa lalu teks dan dirinya. Pemahaman kita akan suatu teks ditentukan oleh kemampuan kita 'mengalami kembali' dan menghayati isi teks tersebut. ${ }^{31}$

Di awal abad ke-20, hermeneutika menjadi sangat filosofis. Dikatan bahwa interpretasi merupakan interaksi keberadaan kita dengan wahana sang Wujud (Sein) yang memanifestasikan dirinya melalui bahasa. Demikian ungkapan Heidegger. ${ }^{32}$ Demikian pula rumusan Hans Georg Gadamer (selanjnutnya disebut Gadamer) yang membayangkan interaksi pembaca dengan teks sebagai sebuah dialog atau dialektika soal jawab, di mana cakrawala kedua belah pihak melebur jadi satu (Horizontverschmelzug), hingga terjadi kesepakatan dan kesepahaman. Menurut Gadamer, Interaksi tersebut tidak boleh berhenti. Setiap jawaban adalah relatif dan tentatif kebenarannya, senantiasa boleh dikritik dan ditolak. ${ }^{33}$

Kembali kepada al-Jabi, jika dirumuskan secara kongkrit sebenarnya model pembacaan terhadap al-Qur'an yang diusung oleh Al-Jabi terdiri dari dua hal utama, pertama, menganalisis kata-kata yang terdapat dalam al-Qur'an menggunakan pendekatan kebahasaan. Dalam hal ini rujukan yang digunakan oleh Al-Jabi adalah kamuskamus bahasa Arab dan syi'r Arab juga beberapa tafsir yang memiliki corak bahasa. Kedua, pendekatan historis-tematis kontekstual terkait

31 Lihat Wilhem Dilthey, “Die Entstehung der Hermeneutik”, Gesammelte Schriften,Gottingen: Vanderhoeck \& Ruprecht, 1957, 317-331

32 Uraiannya dalam Martin Heidegger, "Sein und Zeit", Tubineng: Max Niemeyer, 1993; dalam H. Birus, "Hermeneutische Positionen: Schleiermacher, Dilthey,Heidegger, Gadamer”, Gottingen: Vanderhoeck \& Ruprecht, 19982

33 Lihat Hans-Georg Gadamer, "Wahrheit und Methode: Grunzuge einer Philosophischen Hermeneutik”, Tubbineng: Mohr, 1975 
teks-teks al-Qur'an yang menjadi objek kajian. Tematik dimaksudkan dengan menyajikan seluruh ayat yang terkait. Sedangkan kontekstual dimaksudkan dengan mengkaji ayat sesuai dengan konteks munasabah dan konteks kesejarahannya.

Jika dicermati dengan mendalam sebenarnya apa yang ditawarkan oleh al-Jabi nampaknya sangatlah dipengaruhi oleh hermeneutika Hans georg Gadamer yang mencoba untuk mencarai makna objektif dan tidak terlalu menggunakan subjektifitasnya dalam menafsirkan teks. Adapun teori-teori pokok hermeneutika Gadamer kiranya bisa diringkas ke dalam beberapa bentuk teori yang terkait satu dengan yang lainnya, yaitu:

1. Teori "Kesadaran Keterpengaruhan oleh Sejarah" (wirkungsgeschichtliches Bewusstsein; historically effected consciousness)

2. Teori "Prapemahaman" (Vorverständnis; pre-understanding)

3. Teori "Penggabungan / Asimilasi Horison" (Horizon_ tverschmelzung; fusion of horizons) dan Teori "Lingkaran Hermeneutik" (hermeneutischer Zirkel; hermeneutical circle)

4. Teori "Penerapan/Aplikasi" (Anwendung; application)

Menurut penulis ada dua hal yang dapat menjadikan al-Jabi dipengaruhi oleh Gadamer yaitu pendekatan sejarah yang kemudian dipadukan dengan kajian tematik mencerminkan adanya pemaduan antara pra pemahaman dari penafsir yang dikombinasikan dengan kajian terpadu dari teks yang otoritatif. Sedangkan pendekatan kebahasaan sangatlah terkait dengan upaya menemukan makna sejati di balik teks dan terlebih jika suatu kata memiliki kesejarahaan makna maupun makna yang ambigu dan seterusnya. Keterpengaruhannya dengan Gadamer menjadikan upaya kritik ideal dalam meng-counter pemahaman Syahrur yang cenderung mendahulukan subjektifitasnya disbanding dengan makna objektif dari teks itu sendiri.

Meski demikian hebatnya, namun jika tidak dicermati mendalam, orang akan membaca bahwa pemikiran al-Jabi biasa saja padahal sejatinya ia membangun pondasinya dengan bangunan hermeneutis 
filosofis ala Gadamer, hal ini terkait dengan misinya yang ditujukan untuk mengkritik rumusan hermeneutika Syahrur dalam bukunya “al-Kitab wa al-Qur'an: Qira'at Mu'ashirat" yang mencoba merubah beberapa term dalam al-Qur'an dengan pemahaman yang baru. Oleh karena itu, penulis tidak heran jika kajian yang dilakukan oleh alJabi bukanlah merupakan tawaran yang baru dalam kajian al-Qur'an. Jauh sebelum tawaran al-Jabi dengan dua pendekatan di atas, Imam al-Razi misalnya telah dengan serius menggunakan pendelatan bahasa yang komprehensif dalam mengkaji al-Qur'an melalui magnum opusnya "Mafatih al-Ghaib". Adapun kajian kontekstual yang tematik merupakan model tawaran yang sudah berkembang sejak sebelum Al-Jabi mengembangkan model tersebut, khususnya melalui proyek yang diprakarsai oleh al-Farmawi, salah seorang guru besar di jurusan Tafsir Universitas Al-Azhar Kairo Mesir.

Namun bagi penulis, ada hal yang dilupakan oleh al-Jabi dalam menanggapi Syahrur, jika Syahrur dengan tegas mengatakan "Tsabat al-Nash Wa haraka al-Muhtawa" yakni bahwa teks al-Qur'an boleh saja statis (tetap sesui aslinya namun pemahaman terhadap teks harus selalu mengalami dinamisasi. Dalm hal ini al-Jabi terkesan mengikuti metode yang telah berkembang secara mapan (menjadi tradisi di kalangan akademisi, khususnya tafsir al-Qur'an) sehingga ia pun akan mengkritikusaha-usaha yang dilakukan untuk melakukan pembaharuan dengan kritik layaknya pendekatan yang telah mapan khususnya di kalangan kajian tafsir al-Qur'an. Al-Jabi masih terkungkung dengan kenyamanan metode yang telah berkmbang tanpa berani mencoba memberikan penawaran yang baru.

\section{Penutup}

Salim al-Jabi dalam kitabnya Mujarrad Tanjim (3 jilid), dengan menggunakan kritik yang akademis (bukan kritik ideologis) mencoba membongkar penafsiran Syahrūr dengan menganalisis dan mengeksplorasi makna-makna kebahasaan dan konteks-tekstual ayatayat yang ditafsirkan. Dalam banyak hal dia berkesimpulan bahwa pemikiran Syahrūr tidak sesuai dengan penggunaan makna bahasa Arab sebagaimana yang digunakan dalam kamus-kamus, syi'rsyi'r arab juga beberapa tafsir yang memiliki corak kebahasaan di 
samping pemikirannya juga seringkali tidak sesuai dengan konteks ayat-ayat al-Qur'an. Meskipun terkesan tradisonalis, namun Al-Jabi tidak terkungkung oleh teori munasabat al-ayat yang selama ini berkembang.sayangnya, dalam bukunya ini masih dijumpai kata-kata celaan yang bisa sedikit mengurangi keseriusan kritik ilmiahnya. Yang bisa digolongkan juga ke dalam kritik semacam ini adalah artikelartikel dan buku-buku Nashr Hamid Abu Zayd, yang di dalamnya dia mengkritik, bukan hanya produk penafsiran Syahrūr, melainkan juga apa yang menjadi fondasi hermeneutisnya. Menurutnya, penafsiran Syahrūr mengabaikan historisitas teks al-Qur'an, dalam arti bahwa teks al-Qur'an terkait erat dengan sejarah manusia pada abad ke-7 M., sehingga harus dipahami dengan memperhatikan konteks historis, selain konteks tekstual. 


\section{DAFTAR PUSTAKA}

Ghafur, Waryono Abdul. Tafsir Sosial. Yogyakarta: eLSAQ. 2005.

Fanani, Ahmad Fuad. Islam Mazhab Kritis; Menggagas Keberagaman Liberatif. Jakarta: KOMPAS. 2004.

Gadamer, Hans Georg. Wahrheit und Methode: Grundzüge einer philosophischen Hermeneutik. Tübingen: J. C. B. Mohr, 1990

. "Wahrheit und Methode: Grunzuge einer Philosophischen Hermeneutik". Tubbineng: Mohr. 1975.

“Text and Interpretation", dalam B. R. Wachterhauser (ed.), Hermeneutics and Modern Philosophy. New York: Albany State University of New York Press. 1986.

Hidayat, Kamaruddin. Memahami Bahasa Agama: Sebuah Kajian Hermeneutika .Jakarta: Paramadina. 1996.

Rahman, Fazlur. Islam dan Modernitas Transformatif social, terj. Ahsin Muhammad, Bandung: Pustaka, 1985.

al-Jabi, Salim. al-Qirâât al-Mu'âshirat li al-Duktur Muhammad SYahrur: Mujarrad al-Tanjim. Damaskus: AKAD. 1991.

Syahur, Muhammad. Prinsip dan Dasar Hermeneutika al-Qur'an Kontemporer, terj. Sahiron Syamsuddin. Yogyakarta: eLSAQ Press. 2004.

Ibn Mandhur, Muhammad,Lisân al- 'arob. CD ROM. al-Maktabah alShamilah. Kutub el-Barnamij fi al-lughâh wa al-ma'âjim, Vol 12 ,

Al-Husainy Muhammad.,Taj al'arus min jawâhir al-qomus. CD ROM. al-Maktabah al-Shamilah. Kutub el-Barnamij fi al-lughoh wa al-ma'ajim, Vol 36,

al-Ashfahany, al-Raghib. al-Mufrodât fî ghorîb al-qur'an. Kairo : alMaktabah al-Taufiqiyyah.

Abu Ja'far Al-Thabari, Muhammad bin Jarir bin Yazid bin Katsir bin Ghalib al-Amili,. 'Tafsir al-Thabari'. CD ROM. al-Maktabah al-Shamilah. Kutub el-Barnamij fi al-Tafsir, Vol 9, 